\title{
Teaching for Democratic Action
}

\author{
Joel Westheimer \\ 'University of Ottawa, Ottawa/Ontario - Canada
}

ABSTRACT - Teaching for Democratic Action. Current school reform policies that emphasize standardized tests and a narrow curriculum leave students without skills they need to participate effectively in democratic societies. This article exposes these reforms as inadequate and draws on research regarding school-based programs that seek to teach good citizenship to detail three visions of citizenship commonly found in school programs: personally responsible, participatory, and social justice-oriented. Personally responsible citizenship is the most commonly pursued but has little to do with democratic thought and action. The article concludes with three recommendations for practice.

Keywords: Democracy. Citizenship. Democratic Teaching. Social Justice. Civic Engagement.

RESUMO - Ensino para a Ação Democrática. As políticas atuais de reforma escolar que enfatizam os testes padronizados e um currículo limitado deixam os estudantes carentes de habilidades necessárias para participarem efetivamente em sociedades democráticas. Este artigo apresenta estas reformas como inadequadas, embasando-se em pesquisas referentes a programas escolares que procuram ensinar a boa cidadania para detalhar três visões de cidadania comumente encontradas em programas escolares: pessoalmente responsável, participativo e orientado para a justiça social. A cidadania pessoalmente responsável é a mais comumente buscada, mas tem pouca relação com o pensamento e a ação democrática. O artigo é concluído com três recomendações de prática.

Palavras-chave: Democracia. Cidadania. Ensino Democrático. Justiça Social. Engajamento Cívico.

Educação \& Realidade, Porto Alegre, v. 40, n. 2, p. 465-483, Apr./June 2015 465 http://dx.doi.org/10.1590/2175-623653285 
Teaching for Democratic Action

Imagine $^{1}$ you were visiting a school in a totalitarian nation governed by a single-party dictatorship. Would the educational experiences be markedly different from the ones experienced by children in your local school? That may sound like a facetious question, but I do not intend it that way. It seems plausible that good lessons in multiplication, chemistry, or a foreign language - perhaps with some adjustments for cultural relevance and suitability - would serve equally well in most parts of the world. So if you stepped into a school somewhere on the planet and politely asked to observe some of the lessons, would you be able to tell whether you were visiting a school in a democratic nation or a totalitarian one? Or, conversely, if students from a totalitarian nation were secretly transported to a school in your neighborhood to continue their lessons with new teachers and a new curriculum, would they be able to tell the difference?

The children in your local school would probably learn how to read and write, just like students do in, say, North Korea or China. Students in your local school might learn to add numbers, do fractions, and solve algebraic equations. But that's what students in Uzbekistan learn too. Maybe students in your local school learn not to hit each other, to follow the rules, and not to break any laws. They might sing the national anthem and learn about asteroids and the life-cycle of the glow worm. Maybe they even put on plays, learn a musical instrument and paint pictures. I know of schools in Eritrea and Belarus that do those things too.

My point is that citizens in non-democratic countries governed by a single-party authoritarian regime or even a military junta learn a lot of the same things in school that our children learn. So what goals would be different for schools in a democratic society? For example, do students in democratic countries learn how to participate in public decision-making (the kind of participation that is required for democracy to function properly)? Are they taught to see themselves as individual actors who work in concert with others to create a better society? Are they taught the skills they need to think for themselves and to govern collectively?

Most of us would like to believe that they do. While a school in North Korea, China, or Iran might be teaching students blind allegiance to their nation's leaders and deference to the social and political policies those leaders enact, we would expect that schools in Canada, Brazil, Finland or the United States would teach students the skills and dispositions needed to evaluate for themselves the benefits and drawbacks of particular policies and government practices. We would not be surprised to learn, for example, that North Korean children are taught to abide by an Official History handed down by the single-party authoritarian regime. After all, a school curriculum that teaches one unified, unquestioned version of truth is one of the hallmarks of totalitarian

466 Educação \& Realidade, Porto Alegre, v. 40, n. 2, p. 465-483, Apr./June 2015. 
societies. Democratic citizens, on the other hand, should be committed to the principles and values that underlie democracy - such as political participation, free speech, civil liberties, and social equality. Schools might develop these commitments through lessons in the skills of analysis and exploration, free political expression, and independent thought.

\section{Teaching Questioning - Essential for Schools in Democracies}

Much has been written about the purposes of schools in democratic societies, but here is one characteristic that I believe is essential in distinguishing them from their totalitarian counterparts: schools in democratic societies must teach students how to ask questions - the kinds of questions that are, at times, uncomfortable, the kinds that question tradition. Although most of us would agree that traditions are important, without any questioning, there can be no progress. Students need practice in entertaining multiple perspectives and viewpoints on important issues that affect our lives. These issues can sometimes be controversial. But improving society requires embracing that kind of controversy so that citizens can engage in democratic dialogue and work together toward understanding and enacting the most sensible policy decisions possible.

Why would we expect adults, even senators or members of congress (or parliament), to be able to intelligently and compassionately discuss different viewpoints in the best interests of their constituents if schoolchildren never or rarely get that opportunity in school? School children in classrooms in democratic countries around the world are too often shielded from matters that require thoughtful engagement with today's competing ideas even though that kind of engagement is exactly what democratic participation requires. Although schools habitually avoid controversial issues, engaging controversial issues may be exactly what is called for.

We might think this is obvious - that school reformers would do everything possible to ensure that teachers and students have plenty of opportunities to ask these kinds of questions. And our schools often support democratic dispositions in just such ways. But teaching and learning - in both public and private schools - do not always conform to democratic goals and ideals. Tensions abound, and in recent years some of the very foundations of democratic engagement such as opportunities for independent thinking and critical analysis have become less and less common. If being a good democratic citizen requires thinking critically about important social assumptions, then that foundation of citizenship is at odds with recent trends in global education policy.

Educação \& Realidade, Porto Alegre, v. 40, n. 2, p. 465-483, Apr./June 2015. 
Teaching for Democratic Action

\section{The Attack on Critical Thinking}

In many classrooms around the world, the goals of education have been shifting steadily away from preparing active and engaged public citizens and towards more narrow goals of career preparation and individual economic gain. Pressures from policy-makers, business groups, philanthropic foundations, parents, and a broad cultural shift in educational priorities have resulted in schools being seen primarily as conduits for individual success, and, increasingly, lessons aimed at exploring democratic responsibilities have been crowded out. Much of current education reform is limiting the kinds of teaching and learning that can develop the attitudes, skills, knowledge, and habits necessary for a democratic society to flourish (Berliner, 2011; Kohn, 2004; Llewellyn et al., 2007; Westheimer; Kahne, 2004).

In many school districts, states and provinces, ever more narrow curriculum frameworks emphasize preparing students for standardized assessments in math and literacy at the same time that they shortchange the social studies, history, and even basic citizenship education. Moreover, higher-achieving students, generally from wealthier neighborhoods, are receiving a disproportionate share of the kinds of citizenship education that sharpen students' thinking about issues of public debate and concern. This demographic divide - what some scholars have called the civic opportunity gap - results in unequal distribution of opportunities to practice democratic engagement (see, for example, Kahne; Middaugh, 2008).

Curricular approaches that spoon-feed students to succeed on narrow academic tests teach students that broader critical thinking is optional. In other words, the pedagogical challenge that many educators aim to place at the center of their efforts - how to foster thoughtful consideration and analysis of contemporary problems - has all too often been replaced by the single-minded drive to make students better test-takers, rather than better citizens.

School reform efforts in the United States serve as one example among many and there are many countries that show strikingly similar (and troubling) trends. The high-stakes testing mandated by the U.S. No Child Left Behind (NCLB) and Race to the Top (RTTT) legislation, for example, has further pushed to the margins educational efforts that challenge students to grapple with tough questions about society and the world. In a study by the Center on Education Policy, $71 \%$ of districts reported cutting back on time for other subjects - social studies in particular - to make more space for reading and math instruction (Rentner et al., 2006). Similarly, research by the Washington-based group Common Core found that two thirds of public school teachers surveyed report that disciplines such as science, social studies, and art are crowded out of the school day as a direct result of state testing policies (Common Core and the Farkas Duffett Research Group, 2012). In testimony be-

468 Educação \& Realidade, Porto Alegre, v. 40, n. 2, p. 465-483, Apr./June 2015. 
fore the U.S. Senate, Historian David McCullough noted that, because of NCLB, "[...] history is being put on the back burner or taken off the stove altogether in many or most schools" (Dillon, 2006). An increasing number of students are getting little to no education about how government works, the Constitution, the Bill of Rights, the evolution of social movements, and world history. And when students are denied knowledge about historical events and social movements, they miss out on important opportunities to link their education to the quintessentially democratic struggles for a better society for all.

I focus on history teaching here, but the trend is not limited to social studies. In many schools, virtually every subject area is under scrutiny for any deviation from one single narrative, based on knowable, testable, and purportedly uncontested facts. An English teacher, in a study undertaken by my research team, told us that even novel reading was now prescriptive in her state's rubric: meanings predetermined, vocabulary words preselected, and essay topics predigested. These policies appear in various forms in the education reform movements of most Western democracies.

Finnish educator Pasi Sahlberg calls the kind of school reform that elevates testing and standardization above all other educational considerations GERM (for Global Education Reform Movement). He describes GERM as follows:

It is like an epidemic that spreads and infects education systems through a virus. It travels with pundits, media and politicians. Education systems borrow policies from others and get infected. As a consequence, schools get ill, teachers don't feel well, and kids learn less (Sahlberg, 2012, online)

Not only do kids learn less. What they learn tends to follow prescriptive formulas that match the standardized tests. In the process, more complex and difficult-to-measure learning outcomes get left behind. These include creativity and emotional and social development, but also the kinds of thinking skills associated with robust civic engagement. Teachers' ability to teach critical thinking and students' ability to think and act critically is diminished.

As bad as that sounds, omitting lessons that might develop critical thinking skills is still different from forbidding them. But in the book Pledging Allegiance: The Politics of Patriotism in America's Schools, I detailed the ways that schools, districts, states, and even the federal government - in the wake of the $9 / 11$ terrorist attacks - began to implement policies that actually restrict critical analysis of historical and contemporary events in the school curriculum (Westheimer, 2007). In the worst-case examples, teachers were suspended or fired for teaching lessons on critical analysis of the news or of textbooks, and students were suspended for expressing dissenting opinions on the war in Iraq, orga-

Educação \& Realidade, Porto Alegre, v. 40, n. 2, p. 465-483, Apr./June 2015. 469 
Teaching for Democratic Action

nizing peace clubs, or wearing T-shirts with anti-war quotations. Students and a drama teacher in a Connecticut high school spent months researching, writing, and rehearsing a play they wrote about the Iraq war titled Voices in Conflict. The school administration banned the play on the basis that it was inappropriate. (In this case, the students went on to perform the play in the spring of 2007 on an off-Broadway stage in New York to impressive critical review). But efforts to protect students from multiple perspectives on historical and contemporary events were not limited to individual cases. State and federal policy followed this trend as well.

In 2003, Tennessee Senator Lamar Alexander introduced his bill, "The American History and Civics Education Act," by warning that educators should not expose students to competing ideas in historical texts. Civics, he argued, should be put back in its "rightful place in our schools, so our children can grow up learning what it means to be an American" (Alexander, 2003, n. p.). (For Alexander, what it means to be an American is more answer than question, it seems). In April 2008, the Arizona House of Representatives passed SB 1108 specifying that schools whose teachings "denigrate or encourage dissent" from "American values" would lose state funding (Arizona Legislature, 2008) ${ }^{2}$. More recently, in 2012, the Texas Republican Party platform briefly included language that asserted opposition to "the teaching of critical thinking skills" or lessons that "have the purpose of challenging students' fixed beliefs" (Texas Republican Party, 2012, online).

A more worrisome example, however, comes from Florida. In June 2006, the Florida Education Omnibus Bill included language specifying that "the history of the United States shall be taught as genuine history... American history shall be viewed as factual, not as constructed, shall be viewed as knowable, teachable, and testable" (Craig, 2006, online). The stated goal of the bill's designers was "to raise historical literacy" with a particular emphasis on the "teaching of facts" (see also Immerwahr, 2008). For example, the bill requires that only facts be taught when it comes to discussing the "period of discovery" and the early colonies. This led Florida State Representative Shelley Vana, who also served as the West Palm Beach teachers union president, to wonder just "whose facts would they be, Christopher Columbus's or the Indians?" (Dolinski, 2006). Florida thus became the first state I know of to ban historical interpretation in public schools, thereby effectively outlawing critical thinking.

Of course, professional historians almost universally regard history as exactly a matter of interpretation; indeed, the competing interpretations are what make history so interesting. Historians and educators alike widely derided the mandated adherence to an official story embodied in the Florida legislation, but the impact of such mandates should not be underestimated. The bill and other similar legislative ex-

470 Educação \& Realidade, Porto Alegre, v. 40, n. 2, p. 465-483, Apr./June 2015. 
amples of restricting history lessons to one "true" narrative remain on the books in Florida, Nebraska, Kansas, and other states.

More recently, in the Fall of 2014, more than a thousand Jefferson County, Colorado high school students and hundreds of teachers walked out of classes to protest the school board's efforts to promote "positive" American history and downplay the legacy of civil disobedience and protest. The protests came in the wake of a proposal by the school board to make changes to the Advanced Placement (AP) history curriculum. AP history, the board suggested "should promote citizenship, patriotism, essentials and benefits of the free enterprise system, respect for authority and respect for individual rights. Materials should not encourage or condone civil disorder, social strife or disregard for the law" (Glenza, 2014, online). Responding to the school board's proposal, both teachers and students in Jefferson County boycotted classes, with teachers calling in sick, and students staging a variety of protests outside of schools. One Jefferson County teacher characterized the board's proposal as "[...] an attack on teachers and public education, and a disregard for the needs of our students [...] It's really, really scary to be a teacher in Jefferson County right now," (Glenza, 2014, online) while a high school senior, highlighting the irony of students protesting a curriculum that discourages protesting, vowed: "If they don't teach us civil disobedience, we will teach ourselves" (Jacobs, 2014, online). There is a certain irony, evident in the above examples, to the idea that schools in a democratic nation can better prepare students to be democratic citizens by encouraging deference to authority and discouraging lessons about social movements and social change.

At this point, some readers might be thinking that conditions seem restrictive and anti-democratic for students in the public schools, but that, on the whole, many private schools prepare students for a democratic society by offering a broad liberal education that asks students to grapple with difficult and contested policy issues. Evidence indicates otherwise. As the goals for K-12 public education have shifted away from preparing active and engaged public citizens and toward more narrow goals of career preparation and individual economic gain, private schools have, in many ways, led the pack. Pressures from parents, board members, and a broad cultural shift in educational priorities have resulted in schools across the country being seen primarily as conduits for individual success, and lessons aimed at exploring democratic responsibilities have increasingly been crowded out. A steadily growing body of research in the United States and elsewhere now echoes what Tony Hubbard, former director of the United Kingdom's Independent Schools Inspectorate, stated most plainly after reviewing data from an extensive study of British independent schools: because of the immense pressure to achieve high academic results on exams and elevate schools' prestigious college-entrance rates, independent schools are "over-directed" so that students do not have "sufficient opportunity 
Teaching for Democratic Action

or incentive to think for themselves". Increasingly following formulas that "spoon-feed" students to succeed on narrow academic tests, independent schools, Hubbard warned, "teach students not to think" (BBC News, 2002, online).

Although the overt examples I've described above that seek to ban critical thinking from classrooms are worrisome, the more insidious developments come from an education-reform movement that makes those efforts unnecessary. So many schools have now become myopically focused on efficiency and accountability that there are simply fewer and fewer opportunities for deeper consideration of important ideas. The relentless focus on testing and achievement means that time for in-depth critical analysis of ideas has been diminished. Social studies scholar Stephen Thornton (2005) notes that, by critical thinking, school officials too often mean that students should passively absorb as truth the thinking already completed by someone else. Current school reform policies and many classroom practices too often reduce teaching and learning to exactly the kind of mindless rule-following that makes students unable to make principled stands that have long been associated with democracy. The hidden curriculum of many $21^{\text {st }}$ century curricular programs has become how to please authority and pass the tests, not how to develop convictions and stand up for them.

\section{What Kind of Citizen?}

All is not bleak when it comes to educating for democratic understanding and participation. Many teachers in classrooms around the world conduct excellent educational activities concerned with helping students become active, effective, and thinking citizens. But even when educators are expressly committed to teaching good citizenship, there is cause for caution. My colleague Joseph Kahne and I spent the better part of a decade studying a broad variety of programs that aimed to develop good citizenship skills among youth and young adults. Many of these programs were very explicit about the specific needs of citizens in democratic societies, and so we began to talk openly about the needs of democratic citizens. In study after study, we come to similar conclusions: the kinds of goals and practices commonly represented in curricula that hope to foster democratic citizenship usually have more to do with voluntarism, charity, and obedience than with democracy. In other words, good citizenship to many educators means listening to authority figures, dressing neatly, being nice to neighbors, and helping out at a soup kitchen - not grappling with the kinds of social policy decisions that every citizen in a democratic society needs to learn how to do.

From our studies and with the help of teachers and program leaders, we identified three visions of "good" citizens that help capture the lay of the land when it comes to citizenship education: the Personally Responsible Citizen; the Participatory Citizen; and the Social-Justice Ori- 
ented Citizen (Westheimer; Kahne, 2004). These ideas about good citizenship are like three different answers to this question: What kind of citizen do we need to support an effective democratic society? As the table below illustrates, they can serve as a helpful guide to uncovering the variety of assumptions that fall under the idea of citizenship education (see Table 1).

Personally Responsible Citizens contribute to food or clothing drives when asked and volunteer to help those less fortunate whether in a soup kitchen or a senior-citizen center. They might contribute time, money, or both to charitable causes. Both those in the character education movement and those who advocate community service would emphasize this vision of good citizenship. They seek to build character and personal responsibility by emphasizing honesty, integrity, self-discipline, and hard work. Or they nurture compassion by engaging students in volunteer community service.

Other educators lean toward a vision of the Participatory Citizen. Participatory citizens actively participate in the civic affairs and the social life of the community at local, state/provincial, and national levels. Educational programs designed to support the development of participatory citizens focus on teaching students about how government and other institutions (e.g., community-based organizations, churches) work and about the importance of planning and participating in organized efforts to care for those in need, for example, or in efforts to guide school policies. While the personally responsible citizen would contribute cans of food for the homeless, the participatory citizen might organize the food drive.

A third image of a good citizen, and perhaps the perspective that is least commonly pursued, is of individuals who know how to critically assess multiple perspectives. They are able to examine social, political, and economic structures and explore strategies for change that address root causes of problems. We called this kind of citizen the Social-Justice Oriented Citizen because the programs fostering such citizenship emphasize the need for citizens to be able to think about issues of fairness, equality of opportunity, and democratic engagement. They share with the vision of the Participatory Citizen an emphasis on collective work related to the life and issues of the community. But the nature of these programs gives priority to students thinking independently, looking for ways to improve society, and being thoughtfully informed about a variety of complex social issues. These programs are less likely to emphasize the need for charity and volunteerism as ends in themselves, and more likely to teach about ways to effect systemic change. If Participatory Citizens organize the food drive and Personally Responsible Citizens donate food, the Social-Justice Oriented Citizens - our critical thinkers - ask why people are hungry, then act on what they discover.

Educação \& Realidade, Porto Alegre, v. 40, n. 2, p. 465-483, Apr./June 2015. 
Teaching for Democratic Action

\section{Table 1 - Kinds of Citizens}

\begin{tabular}{|c|c|c|c|}
\hline & $\begin{array}{l}\text { Personally Responsible } \\
\text { Citizen }\end{array}$ & Participatory Citizen & $\begin{array}{l}\text { Social-Justice Oriented } \\
\text { Citizen }\end{array}$ \\
\hline 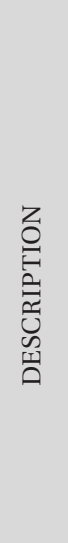 & $\begin{array}{l}\text { Acts responsibly in } \\
\text { their community } \\
\text { Works and pays taxes } \\
\text { Picks up litter, recycles, } \\
\text { and gives blood } \\
\text { Helps those in need, } \\
\text { lends a hand during } \\
\text { times of crisis } \\
\text { Obeys laws }\end{array}$ & $\begin{array}{l}\text { Active member of com- } \\
\text { munity organizations } \\
\text { and/or improvement } \\
\text { efforts } \\
\text { Organizes community } \\
\text { efforts to care for those } \\
\text { in need, promote eco- } \\
\text { nomic development, or } \\
\text { clean up environment } \\
\text { Knows how govern- } \\
\text { ment agencies work } \\
\text { Knows strategies for } \\
\text { accomplishing collec- } \\
\text { tive tasks }\end{array}$ & $\begin{array}{l}\text { Critically assesses } \\
\text { social, political, and } \\
\text { economic structures } \\
\text { Explores strategies } \\
\text { for change that ad- } \\
\text { dress root causes of } \\
\text { problems } \\
\text { Knows about social } \\
\text { movements and how to } \\
\text { effect systemic change } \\
\text { Seeks out and address- } \\
\text { es areas of injustice }\end{array}$ \\
\hline 幽㠩 & $\begin{array}{l}\text { Contributes food to a } \\
\text { food drive }\end{array}$ & $\begin{array}{l}\text { Helps to organize a } \\
\text { food drive }\end{array}$ & $\begin{array}{l}\text { Explores why people } \\
\text { are hungry and acts to } \\
\text { solve root causes }\end{array}$ \\
\hline 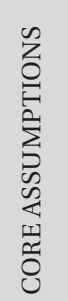 & $\begin{array}{l}\text { To solve social prob- } \\
\text { lems and improve } \\
\text { society, citizens must } \\
\text { have good character; } \\
\text { they must be honest, } \\
\text { responsible, and law- } \\
\text { abiding members of } \\
\text { the community }\end{array}$ & $\begin{array}{l}\text { To solve social prob- } \\
\text { lems and improve } \\
\text { society, citizens must } \\
\text { actively participate } \\
\text { and take leadership } \\
\text { positions within es- } \\
\text { tablished systems and } \\
\text { community structures }\end{array}$ & $\begin{array}{l}\text { To solve social prob- } \\
\text { lems and improve } \\
\text { society, citizens must } \\
\text { question and change } \\
\text { established systems } \\
\text { and structures when } \\
\text { they reproduce pat- } \\
\text { terns of injustice over } \\
\text { time }\end{array}$ \\
\hline
\end{tabular}

Currently, the vast majority of school programs that take the time to teach citizenship are the kind that emphasize either good character (including the importance of volunteering and helping those in need), or technical knowledge of legislatures and how government works. Far less common are schools that teach students to think about root causes of injustice or challenge existing social, economic, and political norms as a means for strengthening democracy.

Recall my earlier question: How would you know the difference between educational experiences in two schools - one in a totalitarian nation and one in a democratic one? Both the totalitarian nation and the democratic one might engage students in volunteer activities in the community - picking up litter from a nearby park perhaps, or helping out at a busy intersection near a school or a senior-citizen center. Gov- 
ernment leaders in a totalitarian regime would be as delighted as leaders in a democracy if their young citizens learned the lessons put forward by many of the proponents of personally responsible citizenship: don't do drugs; show up to work on time; give blood; help others during a flood; recycle; etc. These are all desirable traits for people living in a community. But they are not about democratic citizenship. Efforts to pursue some conceptions of personal responsibility might even undermine efforts to prepare participatory and justice oriented citizens. Obedience and loyalty (common goals of character education), for example, may work against the kind of independent thinking that effective democracy requires.

\section{Teaching for Democratic Action}

There are many varied and powerful ways to develop children's and young adults' capacities to engage in democratic thought and action. While a significant body of work has been written in this regard (for example, Greene, 2000; Kohn, 2004; Noddings, 2007; Shapiro, 2005), I want to focus here on a few of the challenges and possibilities for curriculum aimed in particular at teaching the kind of thinking necessary for democratic societies to flourish. A few examples from research I have conducted in the United States showcase models for change, but I want to be clear that examples such as these can be found in many countries I have visited including England, Switzerland, Italy, Brazil, Guatemala, Argentina, Mexico and Israel (to name a few). They are, however, exceptions rather than the result of deliberate policy efforts. For example, longtime teacher Brian Schultz's inspiring efforts with his 5th grade class in Chicago's Cabrini-Green housing project area included having his students conduct research on improving conditions in their own neighborhood, especially with regard to broken promises to build a new school. His students studied historical approaches to change and, rejecting passivity, demonstrated a deep attachment to their community and neighbors. Their research on urban poverty in Chicago also led them to consider multiple perspectives on its causes, consequences, and possible solutions. Schultz, now a professor at Northeastern Illinois University in Chicago, describes these in his book, Spectacular Things Happen Along the Way (Schultz, 2008).

Bob Peterson, a one-time Wisconsin Elementary Teacher of the Year, worked with his students at La Escuela Fratney in Madison to examine the full spectrum of ideological positions that emerged following the September 11, 2001, terrorist attacks. Instead of avoiding the challenging questions his 5th grade students posed, Peterson encouraged them, placing a notebook prominently at the front of the classroom labeled Questions That We Have. As the students discussed their questions and the unfolding current events, Peterson repeatedly asked students to consider their responsibilities to one another, to their communities,

Educação \& Realidade, Porto Alegre, v. 40, n. 2, p. 465-483, Apr./June 2015. 475 
Teaching for Democratic Action

and to the world. Through poetry (Langston Hughes's Let America Be America Again); historical readings (the Declaration of Independence, the U.S. Constitution, the 1918 Sedition Act); and current events (photographs of September 11 memorial gatherings, protests in the United States and abroad, newspaper editorials), Peterson allowed students to explore political events surrounding the September 11 attacks and their effect on American patriotism and democracy (Peterson, 2007; Westheimer, 2007).

El Puente Academy in the Williamsburg neighborhood of Brooklyn, New York, ties the entire school curriculum to students' and teachers' concerns about the community. Founded by and situated within the El Puente community center and named a New York City School of Excellence, El Puente boasts a $90 \%$ graduation rate in an area where schools usually see only $50 \%$ of their students graduate in 4 years. Former El Puente principal Héctor Calderón attributes the school's success to a curriculum that engages students in community efforts to reverse cycles of poverty and violence, and work toward change in their own neighborhood. Students study environmental hazards in the area, not only because they care about the health of the natural environment, but also because these hazards directly affect the health of the community to which they are deeply committed. Classroom activities are designed to cover basic skills, but also to integrate those skills into meaningful projects that show students the connections between their academic learning and community engagement ${ }^{3}$. El Puente students learn that thinking requires research, analysis, and imaginative interpretation qualities virtually impossible to learn from an exclusive focus on narrow tests of knowledge and skills divorced from social, political, and economic contexts. In one unit, students surveyed the community to chart levels of asthma and identify families affected by the disease. Their report became the first by a community organization to be published in a medical journal. Students and teachers also successfully fought a 55-story incinerator that was proposed for their neighborhood (Gonzales, 1995; North Central Regional Educational Laboratory, 2000; Westheimer, 2005).

These approaches to a curriculum that fosters democratic thinking share several characteristics. First, teachers encourage students to ask questions rather than absorb pat answers - to think about their attachments and commitments to their local, national, and global communities. Second, teachers provide students with the information (including competing narratives) they need to think about subject-matter in substantive ways. Third, they root instruction in local contexts, working within their own specific surroundings and circumstances because it is not possible to teach democratic forms of thinking without providing an environment to think about. This last point makes nationally standardized tests difficult to reconcile with in-depth critical thinking about issues that matter.

476 Educação \& Realidade, Porto Alegre, v. 40, n. 2, p. 465-483, Apr./June 2015. 


\section{Strategies for Change}

If we are to successfully shift curricular goals towards the kinds of critical engagement that democratic thinking requires, the following three strategies can serve as a starting point and as potential levers for change.

\section{Strategy \#1: Go Beyond Facts}

The most common criticism of educators who seek to teach students to think and interpret information is that they have no respect for facts, rigor, and standards. Somehow, critics have become convinced that those who say they want students to think for themselves do not care whether students can read, write, or perform addition or subtraction. This is nonsense. But many educators do want students to know more than facts and formulas. They want the knowledge that students acquire to be embedded in the service of something bigger. It is not enough for students to learn how to read; they also need to learn to decide what is worth reading and why. In other words, they need to learn how to ask questions and engage critically with the world around them.

Proponents of factual history also rapidly lose interest in facts when those facts call into question the one true story. Teaching students to think will require reclaiming common assumptions about what thinking requires. There are few educators who believe that facts are unimportant components of a proper education. But at a time when vast databases of information are at our fingertips in seconds, facts alone represent a profoundly impoverished goal for educational achievement. Furthermore, students tend to learn more facts through thoughtful participation in meaningful projects of concern, but engagement in such projects of democratic importance is rarely driven by the acquisition of facts only. In short, knowledge does not necessarily lead to thoughtful participation. In many programs colleagues and I have studied that emphasized teaching about the workings of democratic government, legislative procedures, elections, and so on, students gained solid factual knowledge without necessarily gaining the inclination or the conviction required to participate (Kahne; Middaugh, 2008; Hess, 2008; Llewellyn et al., 2007). Indeed, we found that often it worked the other way around: participation led to the quest for knowledge. Once students gained experiences in the community, they tended to ask deep and substantive questions that led them to research information they knew little about and, until then, had little inclination to learn.

\section{Strategy \#2: Be Political}

In a lecture on citizenship in the twenty-first century, Harry Boyte (2002, verbal information), co-director of the University of Minnesota's 
Teaching for Democratic Action

Center for Democracy and Citizenship, argued that politics is the way people with different values and from different backgrounds can "work together to solve problems and create common things of value". In this view, politics is the process by which citizens with varied interests and opinions negotiate differences and clarify places where values conflict. Politics is, as Bernard Crick observed in his classic work In Defense of Politics "a great and civilizing activity". To accept the importance of politics is to strive for deliberation and a plurality of views rather than a unified perspective on history, foreign policy, or domestic affairs. If we are to educate thoughtful civically-engaged students, we must reclaim the important place for politics in classrooms in schools. Being political means embracing the kind of controversy and ideological sparring that is the engine of progress in a democracy and that gives education social meaning. The idea that bringing politics into it (now said disdainfully) is a pedagogically questionable act is, perhaps, the biggest threat to engaging students in thoughtful discussion.

\section{Strategy \#3: Embrace Pedagogical Diversity}

Educators who value deep thinking about complex social issues are also those that often make the case that this kind of thinking can only be taught through the kind of "progressive" pedagogy that engages the students in every aspect of the curriculum - deciding what should be taught, choosing the focus of inquiry, researching the issues, and presenting to peers what they have found. A great number of (self-proclaimed) progressive educators insist that only by modeling democracy in the classroom and school can we teach any valuable lessons about what it means to be a thoughtful democratic citizen. After visiting dozens of school programs throughout the United States, Canada, and elsewhere, I am more convinced than ever that the kind of teaching for democracy pursued in schools varies at least as much as the different visions of the good citizen discussed earlier. There is no one pedagogy matched inextricably to certain kinds of educational outcomes.

Daniel Perlstein (2002) wrote a superb study of Mississippi Freedom Schools of the 1960s showing, in part, that although their message was always deeply democratic and oriented towards social justice, their pedagogy was not. Indeed, Lisa Delpit (1995), in The Silenced Dialogue: Power and Pedagogy in Teaching Other People's Children argues persuasively that some Black parents and teachers view progressive pedagogy as a concerted effort to keep less advantaged students from learning the culture of power that progressive change towards justice demands. In her eyes, some parents of African American children would prefer that their children be told exactly what to do, how to spell correctly, the rules of grammar, and so on, because these rules and codes of the culture of power is exactly what their children need to know to get ahead. "If you are not already a participant in the culture of power," Delpit (1995,

478 Educação \& Realidade, Porto Alegre, v. 40, n. 2, p. 465-483, Apr./June 2015. 
p. 127) writes, “[...] being told explicitly the rules of that culture makes acquiring power easier".

The absence of a monolithic relationship between particular teaching strategies and related educational goals works the other way as well. There have been many successful efforts throughout history in teaching profoundly non-democratic, anti-thinking, authoritarian lessons through what appeared to be democratic means. Most of us associate fascism with goose-stepping soldiers marching on order from above. But one need only examine the methods of the Hitler Youth brigades to note how progressive were aspects of their pedagogy - inclusive (within their group at least), community-oriented, highly social, collective, and cooperative (Sunker; Otto, 1997). The medium does not always make the message.

Indeed, one of the fathers of progressive education himself - John Dewey - broke ranks with the Progressive Education Association that he had founded because of the dogmatic homage to child-centered pedagogy that began to grip the organization. In Experience and Education, he writes passionately that "[...] an educational philosophy which professes to be based on the idea of freedom may become as dogmatic as ever was the traditional education which is reacted against" (Dewey, 1916, p. 22).

To be sure, teaching for democratic understanding requires attention to the democratic (or non-democratic nature) of the classroom and the school in which the teaching occurs. But it is clear from examining the myriad of excellent programs that abound that educators need not limit themselves to one particular strategy to achieve democratic learning goals. Rather, truly progressive educators might do better to examine the underlying beliefs and ideological assumptions conveyed by the content of their curriculum. Teaching for democracy and teaching democratically are not always the same. To the extent that an overemphasis on pedagogy detracts from a clear examination of the underlying content and values of the lesson, the conflation of pedagogy and content might serve to conserve rather than transform educational goals. There is no one-size-fits-all solution to teaching children how to think for themselves.

\section{An Invitation to Action}

Almost every school mission statement these days boasts broad goals related to critical thinking, global citizenship, environmental stewardship, and moral character. Yet beneath the rhetoric, increasingly narrow curriculum goals, accountability measures, and standardized testing have reduced too many classroom lessons to the cold, stark pursuit of information and skills without context and without social meaning - what the late education philosopher Maxine Greene called mean and repellent facts. It is not that facts are bad or that they should

Educação \& Realidade, Porto Alegre, v. 40, n. 2, p. 465-483, Apr./June 2015. 
be ignored. But democratic societies require more than citizens who are fact-full. They require citizens who can think and act in ethically thoughtful ways. Schools need the kinds of classroom practices that teach students to recognize ambiguity and conflict in "factual" content and to see human conditions and aspirations as complex and contested.

But education goals, particularly in democratic societies, have always been about more than narrow measures of success, and teachers have often been called upon and appreciated for instilling in their students a sense of purpose, meaning, community, compassion, integrity, imagination, and commitment. Every teacher accomplishes these more artful and ambiguous tasks in different ways. Much as Darwin's theory of natural selection depends on genetic variation, any theory of teaching in a democratic society depends on a multiplicity of ideas, perspectives, and approaches to exploring and seeking solutions to complex issues of widespread concern. Parents, administrators, and politicians alike all must acknowledge that educators in a democratic society have a responsibility to create learning environments that teach students a broad variety of lessons - including but not limited to the kinds of learning goals easily captured by standardized assessments.

For democracy to remain vibrant, educators must convey to students that critical thinking and action are both important components of democratic civic life. Moreover, students must learn that they have important contributions to make. Democracy is not a spectator sport.

Received 19 October 2014 Accepted 29 January 2015

\section{Notes}

1 This article is based on a June 2, 2014 address to teachers, students, and scholars in Porto Alegre, Brazil for the II Seminário Internacional de Educação da Secretaria Estadual da Educação do Rio Grande do Sul/SEDUC. Parts of the article are adapted from Westheimer, 2011 and from earlier research and writing conducted with Joseph Kahne.

2 That bill died on the senate floor but had it passed, schools would have been required to surrender teaching materials to the state superintendent of public instruction, who then could have withheld state aid.

3 The information included here about El Puente is drawn from a research study on democratic schools as well as from subsequent informal visits. See Westheimer (2011).

\section{References}

ALEXANDER, Lamar. Senator Alexander's American History and Civics Bill Passes Senate Unanimously. Press Release, Senator Alexander's office, 20 Jun. 2003.

480 Educação \& Realidade, Porto Alegre, v. 40, n. 2, p. 465-483, Apr./June 2015. 
ARIZONA Legislature. House Bill 1108, Proposed Legislation. 2008. Available at: <http://www.azleg.gov/legtext/48leg/2r/proposed/h.1108rp2.doc.htm>. Accessed on: 25 June 2014.

BBC News. Public schools 'spoon-feed' students. 2002. Available at: <http:// news.bbc.co.uk/1/hi/education/1844620.stm>. Accessed on: 25 June 2014.

BERLINER, David. Rational Responses to High Stakes Testing: the case of curriculum narrowing and the harm that follows. Cambridge Journal of Education, Cambridge, v. 41, n. 3, p. 287-302, 2011.

BOYTE, Harry Chatten. A Different Kind of Politics: John Dewey and the Meaning of Citizenship in the 21st Century. In: Dewey Lecture, University of Michigan, 01 Nov. 2002. [palestra].

COMMON CORE and the Farkas Duffett Research Group. Learning Less: public school teachers describe a narrowing curriculum. Mar. 2012. Available at: <http://commoncore.org/maps/documents/reports/cc-learning-less-marl2. pdf $>$. Accessed on: 25 June 2014.

CRAIG, Bruce. The Coalition Column: history defined in Florida legislature. Perspectives on History, Washington, DC, v. 44, n. 6, p. 16, 2006. Available at: <http://www.historians.org/Perspectives/issues/2006/0609/0609nchl.cfm>. Accessed on: 25 June 2014.

DELPIT, Lisa. The Silenced Dialogue: power and pedagogy in educating other people's children. In: DELPIT, Lisa. Other People's Children: cultural conflict in the classroom. New York: New Press, 1995. P. 119-139.

DEWEY, John. Experience and Education. Carbondale: University of Southern Illinois Press, 1916.

DILLON, Sam. Schools Cut Back Subjects to Push Reading and Math. New York Times, New York, p. Al, 26 Mar. 2006.

DOLINSKI, Catherine. Whose facts? Tampa Tribune, Tampa Bay, p. A5, 18 May 2006.

GLENZA, Jessica. Colorado Teachers Stage Mass Sick-Out to Protest US History Curriculum Changes. The Guardian, London, 30 Sept. 2014. Available at: <http://www.theguardian.com/education/2014/sep/29/colorado-teachers-ushistory-sickout-protest-contracts-jefferson>. Accessed on: 25 June 2014.

GONZALES, David. Alternative Schools: a bridge from hope to social action. New York Times, New York, p. B2, 23 May 1995.

GREENE, Maxine. Releasing the Imagination: Essays on Education, the Arts, and Social Change. New York: Jossey-Bass, 2000.

HESS, Diana. How Schools Can Foster a New Intellectual Freedom: Preventing Tyranny By Nurturing Controversy. New York: Routledge, 2008. [no prelo]

IMMERWAHR, Daniel. The Fact/Narrative Distinction and Student Examinations in History. The History Teacher, Long Beach, v. 41, n. 2, p. 199-206, 2008.

JACOBS, Peter. Colorado High School Students are Protesting a Proposed Curriculum they Say Censors US History. Business Insider, New York, 26 Sept. 2014. Available at: <http://www.businessinsider.com/colorado-students-protestcurriculum-changes-2014-9>. Accessed on: 25 June 2014.

KAHNE, Joseph; MIDDAUGH, Ellen. Democracy for Some: the civic opportunity gap in high school. Washington, DC: The Center for Information and Research on Civic Learning (CIRCLE), 2008. [Working Paper \#59].

Educação \& Realidade, Porto Alegre, v. 40, n. 2, p. 465-483, Apr./June 2015. 
Teaching for Democratic Action

KOHN, Alfie. What Does It Mean to Be Well Educated? Boston: Beacon Press, 2004.

LLEWELLYN, Kristina et al. The State and Potential of Civic Learning in Canada. Ottawa: Canadian Policy Research Network, 2007.

NODDINGS, Nel. Critical Lessons: What Our Schools Should Teach. Cambridge: Cambridge University Press, 2007.

NORTH CENTRAL Regional Educational Laboratory. Viewpoints: v. 7. Small by design - Resizing America's high schools. Naperville: Learning Points Associates, 2000.

PERLSTEIN, Deborah. Minds Stayed on Freedom: Politics and Pedagogy in the African -American Freedom Struggle. American Educational Research Journal, v. 39, p. 249-277, 2002.

PETERSON, Bob. La Escuela Fratney: a journey toward democracy. In: APPLE, Michael; BEANE, James (Ed.). Democratic Schools: lessons in powerful education. Portsmouth: Heinemann, 2007. P. 30-61.

RENTNER, Diane Stark et al. From the Capital to the Classroom: year 4 of the no child left behind act. Washington, D.C.: Center on Education Policy, 2006.

SAHLBERG, Pasi. How GERM is infecting schools around the world. The Washington Post. [The Answer Sheet web log by Valerie Strauss]. 29 june 2012. Available at: <http://www.washingtonpost.com/blogs/answer-sheet/post/how-germis-infecting-schools-around-the-world/2012/06/29/gJQAVELZAW_blog.html>. Accessed on: 25 June 2014.

SCHULTZ, Brian D. Spectacular Things Happen Along the Way: lessons from an Urban Classroom. New York: Teachers College Press, 2008.

SHAPIRO, H. Svi. Losing Heart: The Moral And Spiritual Mis-education of America's Children. New York: Lawrence Erlbaum, 2005.

SUNKER, Heinz; OTTO, Hans-Uwe (Ed.). Education and Fascism. Political identity and social education in Nazi Germany. London: Taylor and Francis, 1997.

TEXAS REPUBLICAN PARTY. Report of Platform Committee and Rules Committee. 2012. Available at: <http://www.tfn.org/site/DocServer/20...pdf?docID=3201>. Accessed on: 26 June 2014.

THORNTON, Stephen. Incorporating Internationalism in the Social Studies Curriculum. In: NODDINGS, Nel (Ed.). Educating Citizens for Global Awareness. New York: Teachers College Press, 2005. P. 81-92.

WESTHEIMER, Joel (Ed.). Pledging Allegiance: the politics of patriotism in american schools. New York: Teachers College Press, 2007.

WESTHEIMER, Joel. No Child Left Thinking: Democracy At-Risk in American Schools and What We Need to Do About It. In: SHAPIRO, H. Svi (Ed.). Education and Hope in Troubled Times: Bold Visions of Change for Our Children's World. New York: Routledge, 2011. P. 259-272.

WESTHEIMER, Joel. Real World Learning: El Puente Academy and Educational Change (Democratic Dialogue occasional paper series). Ottawa, Ontario: DemocraticDialogue.com, 2005.

WESTHEIMER, Joel; KAHNE, Joseph. What kind of citizen? The politics of educating for democracy. American Educational Research Journal, v. 41, n. 2, p 237-269, Summer, 2004

482 Educação \& Realidade, Porto Alegre, v. 40, n. 2, p. 465-483, Apr./June 2015. 
Joel Westheimer is University Research Chair in the Sociology of Education at the University of Ottawa, Canada and education columnist for CBC Radio's Ottawa Morning show. His latest book is What Kind of Citizen? Educating Our Children for the Common Good (Teachers College Press, 2015). Twitter: @joelwestheimer

E-mail: joelw@uOttawa.ca 